\title{
THE GAMETOPHYTES OF CALOPOGON
}

LULA PACE

\author{
(WITH PLATES VII-IX)
}

Photolith plates and edition

This paper reports a continuation of the work on certain orchids begun in 1906. The peculiarities in the development of the megaspores, and in the number and origin of the nuclei in the embryo sac found in Cypripedium (14) made it seem desirable to continue the investigation.

The same methods were used as in the work on Cypripedium. The material of Calopogon pulchellus R. Br. was collected near Chicago in the summer of 1906 . The usual chromacetic and alcoholformalin solutions were carried to the field and the material was killed as collected. The greater part of it has been cut in serial sections five to seven microns thick, and stained in safranin and gentian violet.

\section{MEGASPORES}

The ovules are very numerous and even smaller than those of Cypripedium, the mother cell being five to ten microns in diameter. The archesporium does not seem to be differentiated early. Fig. I shows an ovule pretty well advanced, and yet it is not possible to distinguish an archesporial cell by any difference in staining. The one drawn shows the greatest difference in size in favor of the usual archesporial cell, but other ovules in the same ovary show the other cells of the axial row to be larger; so here also it is probably the cell that is approaching mitosis that is larger. Fig. 2 is taken from another ovary in which the ovules are apparently in the same stage as in fig. $I$. This one suggests a more advanced stage by the broadening of the ovule. Yet this may be related to the appearance of more than the one mother cell, for these ovules with two sporogenous cells are broader, as will be seen later. The first undoubted archesporium seen was in the stage shown in fig. 3. Here the ovule is much larger than in the first two figures and the first integument is beginning. In this ovary more than half of the ovules were in this stage, the archesporial cell being large and showing difference in staining reaction. Botanical Gazette, vol. 48] 
The other ovules were in the mother cell stage (fig. 4). The integument is only a trifle more advanced in the latter than in the former, but the nuclei are in all stages of synapsis. The archesporial cell may become the mother cell without division, and no parietal cell was ever found. But it is possible that in some cases it divides; for an archesporium of more than one cell was rare, being found only once (fig. 26), and yet several ovules with two mother cells in position to have been formed by division of a single archesporial cell were found (figs. 27, 29). It is evident that these must have originated by a division of the archesporial cell, or the archesporium must have consisted of two cells.

A more remarkable case still is that in which two distinct sporogenous areas are differentiated in the same ovule (figs. 28-3I). Fig. $3 I$ shows several cells of nucellar tissue between the two mother cells, the cut being across the ovule in a different direction from that of fig. 28. A somewhat later stage, similar to fig. 28 , is shown in fig. 30 . Fig. 32 shows at least one of the mother cells divided, and one of the resulting daughter cells increasing for the second division, the other disintegrating in the usual fashion. The presence of more than one mother cell is not rare in my material. Of about sixty ovaries cut, thirteen showed ovules with two mother cells, or stages derived from this condition. In these thirteen ovaries, the ovules showing this condition vary from one to seven, giving a total of thirty-seven. Of these thirty-seven, twenty-one are similar to figs. 28 and $3 I$, and sixteen resemble figs. 27 and 29. There was in all probability double this number, for only those were counted in which both cells appeared in the same section. No attempt was made to trace the ovules from section to section for this condition, and it is evident that there are more chances against getting both in the same section than in favor of it. Fig. $3^{I}$ is a drawing from a single section, but the whole ovule was traced carefully from section to section for evidence of the coalescence of two ovules. The only abnormal appearance was the unusually broad funiculus. Fig. 33 shows the megaspores derived from the two adjacent mother cells. In each case the chalazal megaspore is developing and the other three are disintegrating. In the lower or micropylar group the megaspores are in a row-the usual row of four, except that the wall is lacking between the two upper megaspore 
nuclei. In the upper or chalazal group two of them lie side by side without a separating wall. The upper two are in the normal position, but the usual separating wall is lacking. Fig. 34 seems to show an embryo sac of two nuclei derived from the chalazal group of two mother cells. The three disintegrating nuclei are probably megaspore nuclei, and the micropylar mother cell has not divided. Fig. 35 is taken from a much younger ovule, but a very broad one. It seems to be the product of two sporogenous cells, the chalazal mother cell having divided to form the two daughter nuclei, the micropylar mother cell being still in metaphase. It is possible that this is the result of the second division of the chalazal daughter cell without walls separating the two megaspore nuclei, the micropylar daughter cell being still in mitosis. But the chromosomes in this nucleus give every appearance of the heterotypic division, and the ovule is so unusual in appearance that it seems to have had two mother cells.

Synapsis continues for some time, if the extent of development of the integument be considered proof (figs. 4, 5). The division of the mother cell takes place in the usual way (figs. 5-Io), giving the two daughter cells (fig. II). The number of chromosomes is apparently thirteen ( $f i g .6$ ), although only a few counts were made, but this one seemed unusually distinct, so it is probably the correct number. Several counts were attempted in a sporophytic area, giving approximately twenty-six. It is probable that sometimes the wall separating the daughter nuclei fails to appear. Fig. 9 would be expected to show some evidence of wall formation, if it were going to appear. Fig. I5 shows the division completed, with no suggestion of a wall. Fig. I6 gives no wall. Several examples of this failure of the wall were found, and in others it seemed very faint and probably disappeared.

In many plants the chalazal daughter cell divides; but in Calopogon it seems quite common for both to divide, although the micropylar cell is even then somewhat smaller than the chalazal cell (figs. I3, I4). These divisions may occur at the same time as in the above figures, or either may precede the other. Figs. I7 and 18 show the chalazal cell dividing first, the former showing the micropylar cell somewhat more advanced than the latter. In fig. Ig the micropylar daughter cell has almost completed the division, while the chalazal 
cell is still in the spirem stage. This does not appear so often as the other in my material. At this division of the daughter cells the walls begin to form in the usual way (figs. 14, I8, 19), though in a few instances no evidence of wall formation was seen (figs. I7, 20). But the walls all disappear, if they were ever found in these cells (figs. 20, 28 ), for no case of a wall at this stage was seen, though hundreds of examples like those figured were found. After this division the micropylar nucleus from the inner daughter cell begins to disintegrate (figs. 2I, 22), although it may sometimes divide (fig. 24). Fig. 23 shows both daughter cells divided, with one megaspore nucleus in each case disintegrating. While apparently two of the megaspores are active, one of them is already in advance of the other, judging by size of nucleus and cell. Fig. 24 shows the micropylar daughter cell with the nucleus in metaphase, while fig. 25 is only late spirem. Probably the former would have completed the division. Figs. 24 and 25 are also interesting as the only cases seen in which the megaspore nucleus that usually disintegrates in the sac shows evidence of further development. In the first it has divided, while in the second it is in the spirem stage, yet in both cases it is evidently disintegrating. The megaspore that is to form the sac in fig. 25 is in mitosis with the spindle well formed.

\section{EMBRYO SAC}

As the walls disappear, or never develop, in the division of the daughter cells, the two megaspore nuclei are left in the embryo sac. The micropylar nucleus apparently always disintegrates, as does the cytoplasm about this nucleus (figs. $21,22,23,48$ ). This leaves only one megaspore nucleus, probably one might say only one megaspore, to enter into the organization of the embryo sac. This nucleus divides, giving a sac with two nuclei (fig. 46). The three other bodies in the sac are probably the three disintegrating megaspore nuclei. The two nuclei of the sac divide simultaneously (fig. 47), giving a four-nucleate sac (fig. 48). This figure is interesting because the three disintegrating megaspore nuclei are easily identified at this late stage. Fig. 49 shows about the same stage, except that the sac has increased in size and the nuclei are preparing for the next division, although there are still traces of the spindles of the preceding 
mitosis. These spindles show no traces of wall formation. The micropylar daughter cell did not divide here, although the nucleus completed the prophase, even forming the chromosomes. There is just a trace of the disintegrating megaspore nucleus in the sac. The four nuclei in the sac increase in size and divide in the usual fashion (fig. 50). The two dark bodies in the lower part of this sac are probably the remains of the micropylar daughter cell and the disintegrating megaspore nucleus. This division gives eight nuclei in the sac (fig. 5I). By comparing figs. $5^{I}$ and 52 it can be seen that one of the four nuclei at the lower end passes up toward the center, and the sister to the egg moves down in the usual position for the two polar nuclei. The eight nuclei arrange themselves in the usual way-an egg apparatus of two synergids and the egg in the micropylar end of the sac, three antipodals in the chalazal end, and the two polars near the center (figs. 52, 53). Fig. 53 shows a pollen tube already forcing its way between the integuments, about halfway to the sac.

\section{MICROSPORES AND MALE GAMETOPHYTE}

The pollen in Calopogon is in masses or pollinia, as it is in many of the orchids. Each massula is apparently the group of cells resulting from the division of each sporogenous cell ( $f g .36$ ). The whole sporogenous area probably reaches the mother cell stage at the same time (fig. 37). The mother cells divide in the usual way, by the so-called simultaneous division, which is thought to be more characteristic of dicotyledons than of monocotyledons, although found in both groups (Coulter and Chamberlain 7, p. I2I). This gives the tetrad form in some cases, but in others the four spores lie in any plane (figs. $38-42$ ). The microspore nucleus divides into the tube and generative nuclei while the pollen is still in the sac ( $f i g .43)$. Pollen tubes are numerous in the ovary, in some cases at least, when ovules are still in the mother cell stage, like fig. 5 , although no pollen tube was ever seen in contact with an ovule at this stage. Figs. $4 I$ and 42 are examples of pollen tubes within the ovary, before entering the ovules. In these the generative nucleus had already divided into the two male nuclei, so it is probable that this division takes place when the pollen grain germinates. 


\section{FERTILIZATION}

As has been said, the embryo sac when ready for fertilization contains eight nuclei, arranged in the usual fashion-the egg apparatus of two synergids and an egg in the micropylar end, three antipodals at the opposite end, and the two polars about the center of the sac (fig. 53). When the pollen tube is entering the sac, the egg and the polar nuclei may be in late spirem stage $(f i g .54)$. In $f i g .55$ the two polars have already formed chromosomes. Fig. 56 shows the fusion of a male nucleus with the egg, and the triple fusion in the center of the sac is undoubtedly that of the two polars and the second male nucleus. Not very much material was examined at this stage. But in all that was seen there was every indication that this is the usual condition.

\section{DISCUSSION}

Sporogenous cells.-BOWER (3) states that a multicellular archesporium is found in several of the archichlamydeous dicotyledons, especially in Amentiferae, Rananculaceae, Rosaceae; but that it is apparently rare in more advanced dicotyledons and in the monocotyledons. GUIGNARD (9) reports Ornithogalum pyrenaicum with an archesporium of two cells, only one of which gets beyond the archesporial stage. BARNARD (I) reports two embryo sacs in Lilium candidum. Coulter and Chamberlain (7, p. 6r) say that they have seen one preparation of Lilium philadelphicum with three archesporial cells and another with five; but no figures are given. FERGuson (8) in a note figures two mother cells in Lilium longiflorum with intervening nucellar tissue. But, as has already been shown, there are many such cases in Calopogon, thirty-seven cases of two mother cells or stages evidently derived from them being seen, in thirteen ovaries out of about sixty cut, and this probably represents less than half the number actually present. So while this condition is very far from being the usual one in my material, it could hardly be called rare, and therefore abnormal. It seems best to regard it as a primitive character that has been retained, or at least not entirely eliminated. SARGANT (I5) and others hold that monocotyledons are derived from dicotyledons. This occasional appearance of a multicellular archesporium may indicate that the dicotyledons from which these came 
still had a multicellular archesporium, as the more primitive dicotyledons do yet.

Megaspores.-There are usually four megaspore nuclei formed. However, in a few instances, only one daughter cell divided. In many cases the wall separating these megaspore nuclei at the second division was seen to be forming (figs. I4, I6, I9) but always it had disappeared at maturity (figs. 20, 23). In a few cases there was no indication of a wall forming (figs. $15,17,20$ ). This omission of all cell formation in the second division is the condition found in Cypripedium (14). The fact that Calopogon usually has the four megaspore nuclei was rather unexpected in this highly specialized group of the monocotyledons. For the tendency is not only to a row of three, due to the failure of one of the daughter nuclei to divide, but to the condition known as the mother cell functioning as a megaspore (Coulter and Chamberlain 7, p. 80), which is common in monocotyledons. Schniewind-Thies (I6) has shown that in Lilium the heterotypic division takes place within the embryo sac, only ephemeral walls being formed in either of the divisions from the mother cell to the megaspore. In Cypripedium it was found (14) that no wall appeared at the second division, and that two megaspore nuclei are used in forming the embryo sac. Coulter has shown (6) that this may be a very important point in connection with embryo sacs of more than eight nuclei. For if more than one megaspore nucleus enters into the organization of the sac, it is evident that more than eight nuclei in the sac would be the result of the usual five divisions from mother cell to egg found in angiosperms. So that while Cypripedium with its four-nucleate sac seems more reduced than Lilium, it really has just the same number of divisions from mother cell to egg (I4).

Brown (4) objects to calling these nuclei in Cypripedium megaspore nuclei, yet he proceeds to do it in Peperomia, although there is only the additional evidence of ephemeral walls. JoHnson (I I) has also shown these four nuclei in the tetrad position in Peperomia. The origin of the nuclei is identical in both Cypripedium and Peperomia, with the usual megaspore story except in the matter of wall-a mother cell passing from synapsis through the heterotypic and homotypic divisions. In Cypripedium a permanent wall appears at the heterotypic division, but none at all at the homotypic; in Peperomia 
ephemeral walls appear at both divisions. This gives apparently four megaspore nuclei forming the sac in Peperomia, while only two enter into its organization in Cypripedium. It might be better to select another name for these nuclei, but it would always involve the explanation of their similarity to megaspore nuclei, with apparently no gain in clearness. For our notion of spores, extending back through pteridophytes and bryophytes, is that when a mother cell divides there are four spores produced, the spore being the cell formed by the heterotypic and homotypic divisions. The matter of walls would not seem to be so important as the behavior of the nuclear materials; for all sorts of variation in the kinds and shapes of these are found, these differences being related apparently to the environment of the spore. The egg is of course a descendant of only one megaspore, however many may enter into the construction of the sac. And it seems to involve less change from what have seemed to be the essentials to regard these as megaspore nuclei than to conceive of a mother cell functioning directly as a megaspore and yet proceeding to the very same heterotypic and homotypic divisions. This is more evident still when Calopogon is taken into consideration, as it seems to present a stage that might be considered intermediate between Cypripedium and the usual one. For here there are certainly two megaspore nuclei in the sac, one finally disintegrating, although some evidence of its division is present in two cases examined (figs. 24, 25).

This lack of walls is not very rare. LLOyd (I2) reports them as usually absent in Rubiaceae, although the tetrad is formed. Here only one megaspore nucleus functions. The same condition is reported by Cannon (5) in Avena, and by SMITH (17) in Eichhornia. WIEgAND (I9) finds the second divisions unaccompanied by walls in Potamogeton foliosus, and Holferty (10) finds the wall omitted in the division of the micropylar daughter cell in Potamogeton natans. BILlings (2) reports one case of megaspores without separating walls in Tillandsia usneoides. And the many cases where the mother cell is said to function as a megaspore seem to represent the same condition, except that the non-functioning megaspores not only do not disintegrate but even divide and thus contribute to the contents of the embryo sac.

In Calopogon only one megaspore nucleus is used in forming 
the sac, though two are certainly in it (figs. 2I, 22), just as in Cypripedium. Both may divide, though no evidence beyond a late spirem or metaphase stage was seen, except in one case (fig. 24), and here the usual disintegration was taking place. So in this respect Calopogon might be regarded as suggesting what may have taken place in the ancestry of Cypripedium, as it passed from the usual tetrad or row of three to its present condition.

Fertilization.-So-called double fertilization is present here as in Cypripedium. It will be remembered that NaWASchIN (I3) reports it lacking in certain tropical orchids, while STRASBURGER (I8) found it in orchids he investigated.

\section{SUMMARY}

r. There is usually one sporogenous cell which becomes the mother cell. But in many cases two mother cells are found, either contiguous or with nucellar tissue between.

2. Four megaspore nuclei are usually formed; occasionally the micropylar daughter cells in the second division either never appear or are ephemeral. This leaves two megaspore nuclei in the sac. But three of these megaspore nuclei disintegrate, the two from the micropylar daughter cell and the micropylar one in the sac.

3. The embryo sac is the usual eight-nucleate kind, developed in the usual way.

4. Pollinia are in massulae in four loculi. Tetrads are in any position, but there is no rounding-up of pollen grains. Tube and generative nuclei are formed before the pollen escapes. The pollen tube shows a tube nucleus and two male nuclei as it enters the ovary.

5. Double fertilization occurs.

BAYLOR UNIVERSITY

Waco, Texas

\section{LITERATURE CITED}

x. BARNARD, C. H., Recherches sur les sphères attractives chez Lilium candidum. Jour. Botanique I 4 : I18-I24, I77-I88, 206-212. pls. 4, 5. I900.

2. Billings, F. H., A study of Tillandsia usneoides. Bot. Gazetre 38:99I2I. pls. 8, 9. I905.

3. BOWER, F. O., The origin of a land flora 97. 1908.

4. Brown, W. H., The nature of the embryo sac of Peperomia. Bot. Gazetre 46:445-460. pls. 3I-33. Igo8. 
5. Cannon, W. A., A morphological study of the flower and embryo of the wild oat, Avena fatua. $\quad$ Proc. Calif. Acad. Sci. III. I:329-364. pls. 49-53. I900.

6. Coulter, J. M., Relation of megaspores to embryo sacs in angiosperms. Bot. Gazette 45:36I-368. I908.

7. Coulter and Chambertain, Morphology of angiosperms 8o. Igo3.

8. Ferguson, M. C., Two embryo sacs in Lilium longiflorum. Bот. Gazette 43:418, 4I9. fig. I. I908.

9. Guignard, L., Recherches sur le sac embryonnaire des phanérogames angiospermes. Ann. Sci. Nat. Bot. VI. I 3 : I36-199. pls. 3-7. I882.

io. Holferty, G. M., Ovule and embryo of Potamogeton natans. Bot. Gazette 3r:339-346. pls. 2, 3. rgor.

Ir. Johnson, D. S., A new type of embryo sac in Peperomia. Johns Hopkins University Circular $195: 19-21$. pls. 5, 6. 1907.

12. Lloyd, F. E., The comparative embryology of Rubiaceae. Mem. Torr. Bot. Club 8:27-II2. pls. 8-15. I902.

r. Nawaschin, S., Doppelte Befruchtung bei den Orchideen. Ber. Deutsch. Bot. Gesells. 18:224-230. pl. g. Igoo.

14. Pace, L., Fertilization in Cypripedium. Bot. Gazette 44:353-374. pls. 24-27. 1907 .

I5. SARgant, E., The reconstruction of a race of primitive angiosperms. Annals of Botany 22:I2I-I86. figs. I-21. I908.

r6. Schniewind-Thies, J., Die Reduktion der Chromosomenzahl und die ihr folgenden Kernteilungen in den Embryosack-Mutterzellen der Angiospermen. Jena. rgor.

I7. Sмтth, R. W., A contribution to the life-history of the Pontederiaceae. Вот. GAZETTE 25:324-337. pls. 19, 20. I898.

r8. Strasburger, E., Einige Bemerkungen zur Frage nach der doppelten Befruchtung bei den Angiospermen. Bot. Zeit. 58:290-316. I900.

I9. WIFGAND, K. M., The development of the embryo sac in some monocotyledonous plants. Вот. GAZETte 30:25-47. pls. 6, 7. I900.

\section{EXPLANATION OF PLATES VII-IX}

All figures were drawn with a Bausch and Lomb camera. Fig. 8 was made with Leitz no. 4 ocular and no. 7 objective, and fig. 36 with no. 2 ocular and no. 7 objective; all others with Leitz no. 4 ocular and Bausch and Lomb $\frac{1}{12}$ objective.

The abbreviations used are as follows: $c$ chalazal daughter cell and nucleus; $e$ egg; $g$ generative nucleus; $g c$ generative cell; $m$ micropylar daughter nucleus; $m s$ megaspore nucleus; $p$ polar nucleus; $s$ synergid; $t$ tube nucleus; $\sigma^{\nearrow}$ male nucleus.

Fig. I.-Young ovule.

\section{PLATE VII}

Fig. 2.-Young ovule with broader funiculus.

FIg. 3.-Archesporial cell differentiated; beginning of the integument.

Fig. 4.-Mother cell; synapsis almost complete. 
FIG. 5.-Synaptic knot complete; integument much older.

Fig. 6.-Metaphase; thirteen chromosomes; multipolar spindle.

Fig. 7.-Spindle for division of mother cell.

Fig. 8.-Mother cell in same stages as fig. 7, but integuments much farther advanced.

Fig. 9.-Late anaphase; no evidence of wall formation.

FIG. Io.-Late telophase; wall separating the daughter nuclei.

Fig. I I. - Two daughter cells.

FIG. I2.-Two daughter cells, one of which is disintegrating.

Fig. 13.-Two daughter cells in mitosis.

Fig. 14.-Two daughter cells in telophase with walls forming; these are the megaspores.

FIG. 15.-Two daughter nuclei with no wall separating them; traces of the spindle still present.

FIG. I6.-Two daughter nuclei with no separating wall, but one of them larger than the other.

Fig. 17.-Chalazal daughter cell in telophase, with no trace of wall; micropylar daughter cell with chromosomes formed for division.

FIG. I8.-Chalazal daughter cell in telophase, with beginning of wall formation; micropylar daughter cell shows a slight thickening of the spirem.

\section{PLATE VIII}

Fig. 19.-Chalazal daughter cell in prophase; spirem short and thick; micropylar daughter cell in late telophase with wall forming.

Fig. 20.-Two megaspore nuclei of equal size; micropylar daughter cell undivided.

Fig. 21.-Embryo sac beginning to increase in size; one megaspore nucleus beginning to show evidence of mitosis; another megaspore nucleus disintegrating within the sac; the two megaspore nuclei from the micropylar daughter cell also disintegrating, with slight traces of the spindle still present.

Fig. 22.-About the same stage as fig. 20.

Fig. 23.-Four megaspore nuclei, one from each of the daughter cells disintegrating with its own cytoplasm, the other one in each case in good condition for development, although the chalazal nucleus is the larger.

Fig. 24.-Micropylar daughter cell with chromosomes formed for mitosis; one megaspore nucleus in sac developing, the other already divided, and both nuclei disintegrating.

Fig. 25.-Chalazal megaspore nucleus with spindle; the other megaspore nucleus in the sac in late spirem, or metaphase; the micropylar daughter cell nucleus in spirem stage.

Fig. 26.-Two sporogenous cells in one ovule.

Fig. 27.-Two mother cells in one ovule.

FIG. 28.-Two mother cells with nucellar tissue between them.

Fig. 29.-Two mother cells. 


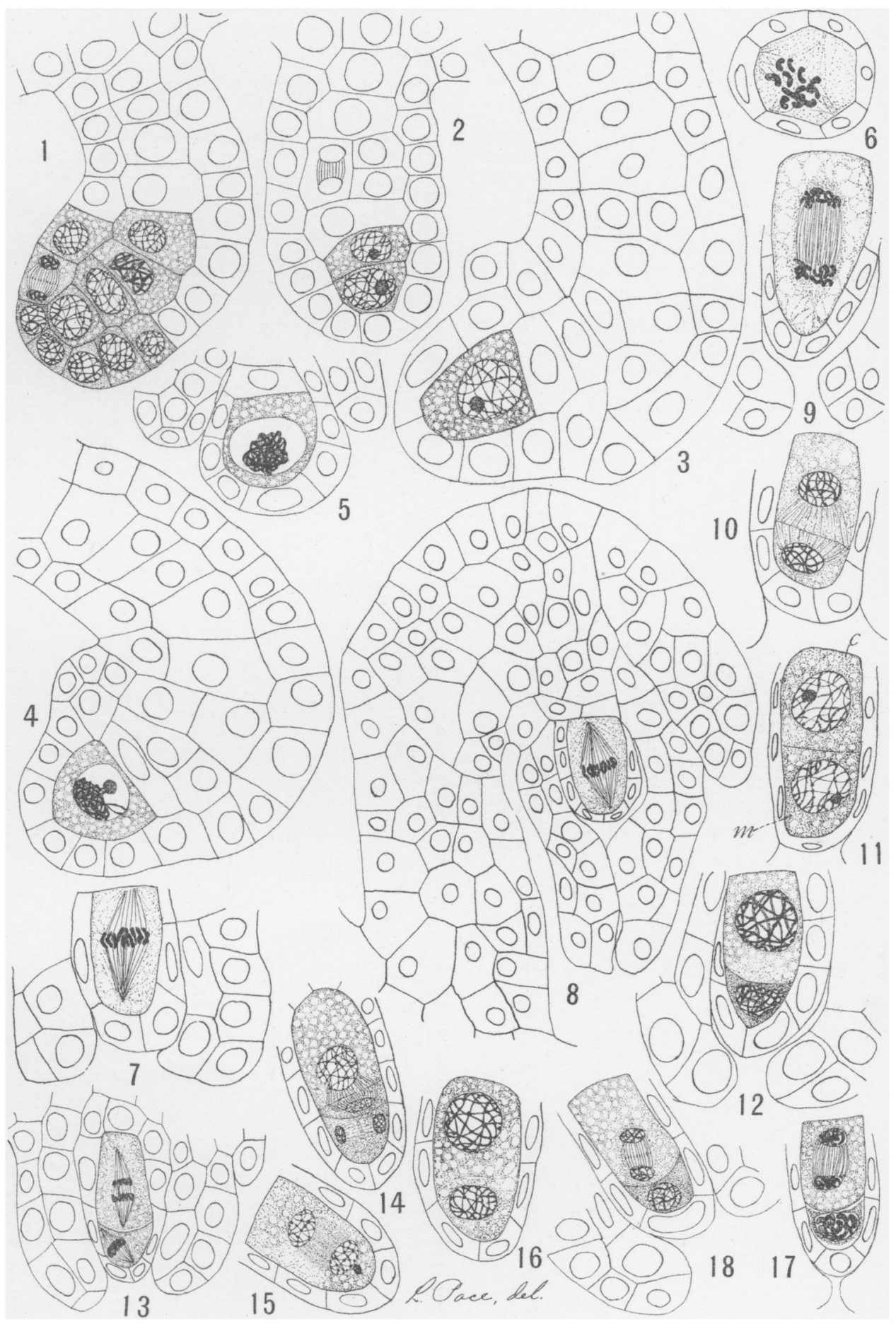

PACE ON GALOPOGON

This content downloaded from 080.082.077.083 on February 19, 2018 18:29:39 PM All use subject to University of Chicago Press Terms and Conditions (http://www.journals.uchicago.edu/t-and-c). 


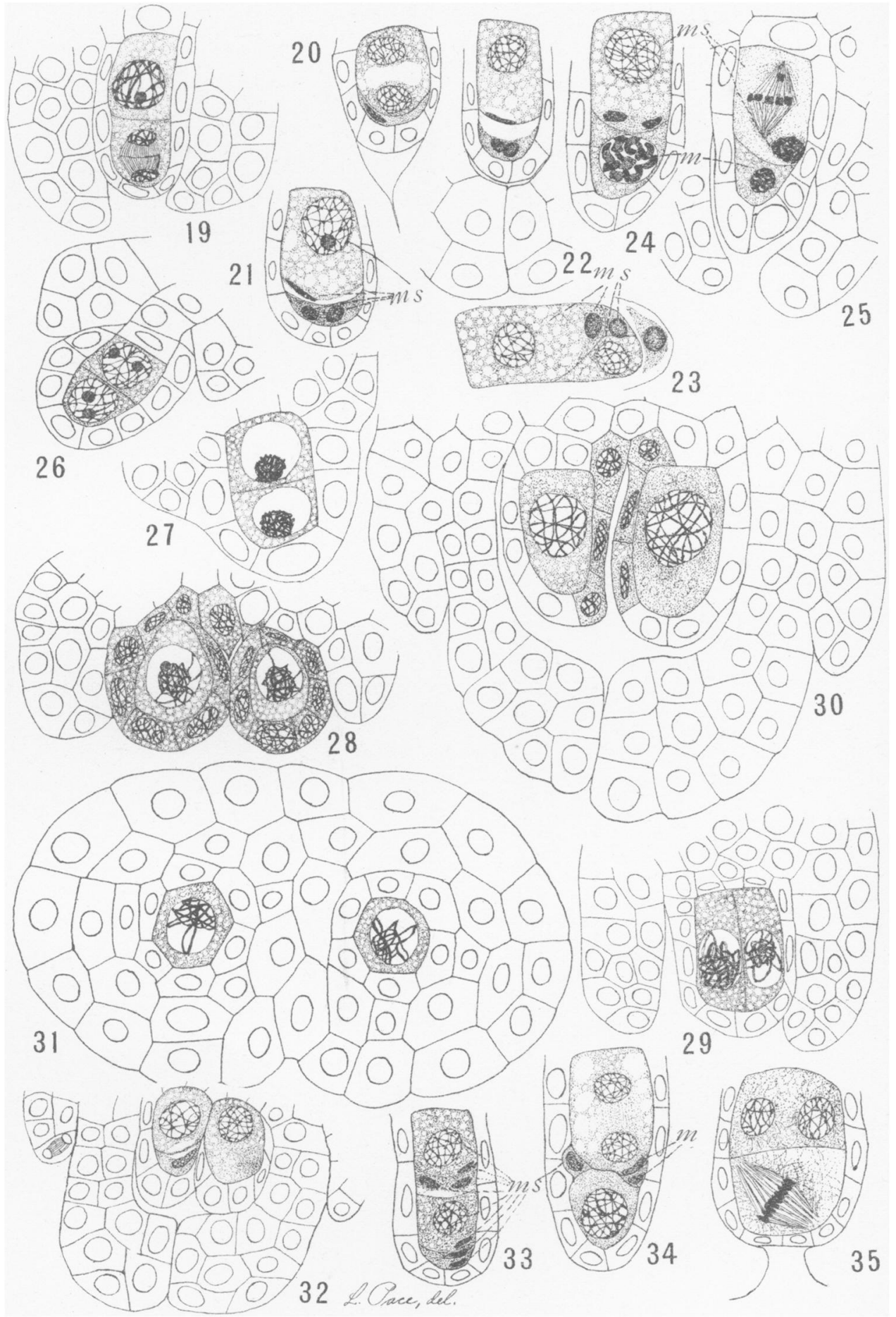




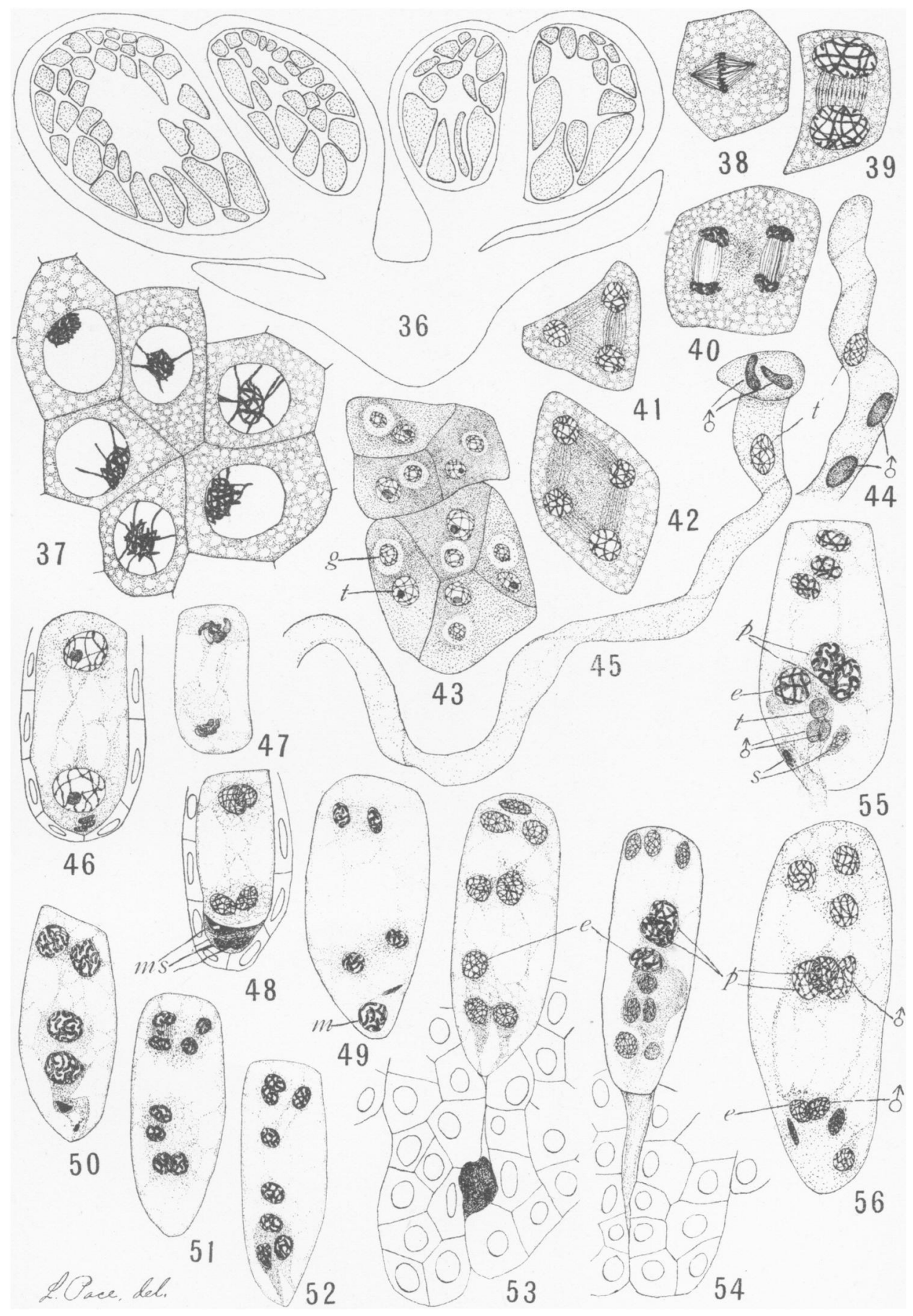


Fig. 30.-Two mother cells after recovery from synapsis.

FIG. 3I.-Two mother cells with several cells of nucellar tissue between; ovule cut across.

FIG. 32.-Ovule with two daughter cells; and probably another mother cell beside it, or another daughter cell with slight traces of the second disintegrating.

FIG. 33.-Eight megaspores from two mother cells.

FIG. 34.-Two-celled embryo sac, three disintegrating megaspore nuclei, and a mother cell recovered from synapsis.

FIG. 35.-One mother cell in metaphase, the other already divided, giving two daughter nuclei without separating wall.

\section{PLATE IX}

Fig. 36.-Diagram of anther, showing four pollen masses; massulae shaded.

FIG. 37.-Pollen mother cells in synapsis.

FIG. 38.-Pollen mother cell with spindle.

Fig. 39.-Pollen mother cell in telophase.

FIG. 40.-Telophase of second division.

FIGs. 4r, 42.-Pollen tetrad; microspore nuclei.

FIG. 43.- Two tetrads, each pollen grain of which shows tube and generative nucleus.

FIG. 44.-Pollen tube from within ovary.

Fig. 45.-Pollen tube near ovule.

Fig. 46.-Two-celled embryo sac.

FIG. 47.-Both nuclei in sac in mitosis.

FIG. 48.-Four-celled embryo sac: three disintegrating megaspores.

FrG. 49.-Four-celled sac; traces of spindle of preceding division; megaspore nucleus within sac disintegrating.

FIG. 50.-Four-celled sac; prophase for next division; traces of disintegrating megaspore nucleus and micropylar daughter cell.

FIG. 51.-Eight-celled sac; traces of spindles of preceding division.

FIG. 52.-Nuclei beginning to assume usual position in sac.

FIG. 53.- Sac ready for fertilization; egg apparatus of egg and two synergids; two polars, one a sister to the egg; three antipodals; pollen tube between integuments.

FIG. 54.- Pollen tube within the sac; egg and two polars in late spirem or metaphase.

Fig. 55-- Pollen tube in sac; egg with thick spirem; polars with chromosomes.

Fic. 56.-Double fertilization. 